\title{
Justice Thomas's Kelo Dissent: The Perilous and Political Nature of Public Purpose
}

Carol Necole Brown

University of North Carolina (UNC) at Chapel Hill - School of Law, cbrown5@richmond.edu

\section{Recommended Citation}

Carol N. Brown, Justice Thomas's Kelo Dissent: The Perilous and Political Nature of Public Purpose, (2016).

Available at: https://scholarship.law.ua.edu/fac_working_papers/387

This Working Paper is brought to you for free and open access by the Faculty Scholarship at Alabama Law Scholarly Commons. It has been accepted for inclusion in Working Papers by an authorized administrator of Alabama Law Scholarly Commons. 


\title{
JUSTICE THOMAS'S KELO DISSENT: THE PERILOUS AND POLITICAL NATURE OF PUBLIC PURPOSE
}

\author{
Carol Necole Brown*
}

\section{INTRODUCTION}

The exercise of eminent domain in the United States has victimized politically disadvantaged groups like minorities and the poor the most. ${ }^{1}$ As Professor Ilya Somin aptly noted in his recent book, The Grasping Hand, "[w]ealthy and politically connected property owners rarely suffer from economic development . . . takings, because politicians and developers are usually savvy enough to avoid targeting them."2 Whether it is government taking private property for highways, roads, or schools, the common thread that weaves through all of these examples-from the beginning of the country until now-is that political actors have always decided whose property was to be taken. ${ }^{3}$ Since the beginning of time, the least powerful groups have always had the least political influence. ${ }^{4}$ And, people with the least political power are the people who pay the price of eminent domain. ${ }^{5}$

\footnotetext{
* Professor of Law, University of Richmond School of Law. Thank you to the University of Richmond School of Law and Dean Wendy Perdue and Corinna Barrett Lain for their support of this project. Thank you to my parents, the late Allen S. Brown and the late Valerie J. Brown, as well as to my husband, Paul Clinton Harris, Sr., and my daughters Reagan Mackenzie Harris and Hannah Madison Harris.

1 Kelo v. City of New London, 545 U.S. 469, 521-22 (2005) (Thomas, J., dissenting); Brief of Amici Curiae NAACP et al. in Support of Petitioners at 3, Kelo, 545 U.S. 469 (2005) (No. 04-108), 2004 WL 2811057, at *3; Carol Necole Brown, Kelo v. City of New London and the Prospects for Development After a Natural Disaster, in Private Property, Community Development, AND Eminent Domain 149, 164 (ed. Robin Paul Malloy 2008); Dick M. Carpenter \& John K. Ross, Testing O’Connor and Thomas: Does the Use of Eminent Domain Target Poor and Minority Communities?, 46 URB. STUD. 2447, 2456 (2009).

2 Ilya Somin, The Grasping Hand: Kelo V. City of NEW London AND the Limits of EMINENT DOMAIN 101 (2015).

3 Brief of Amici Curiae NAACP et al. in Support of Petitioners, supra note 1, at 11 (discussing economic statistics that prove that historically disenfranchised groups are disproportionately and negatively impacted by economic-development takings); Kevin Douglas Kuswa, Suburbification, Segregation, and the Consolidation of the Highway Machine, 3 J.L. Soc’y 31, 53 (2002) (discussing the Interstate Highway Act of 1956 and its contribution to housing discrimination); Charles Toutant, Alleging Race-Based Condemnation, N.J. L.J., Aug. 2, 2004, at 357.

4 Brief of Amici Curiae NAACP et al. in Support of Petitioners, supra note 1, at 11 (stating that racial and ethnic minorities and the elderly and economically disadvantaged suffer disproportionately from economic-development takings because they are easier economic and political targets and are therefore less able to contest government's actions); Douglas J. Amy, What is Really Wrong with Government, GOV'T IS GOOD, http://www.governmentisgood.com/articles.php?aid=23 (last visited Jan. 9,
} 
The United States Supreme Court in Kelo v. City of New London ${ }^{6}$ doubled down on this tragedy when it blessed economic-development takings. ${ }^{7}$ An economic-development taking refers to the government's use of the power of eminent domain to take private property for the public purpose of economic development—creating economic advantages. ${ }^{8}$ Often times, economic-development takings like the one in Kelo take private property from one party and transfer it to another private party. The notion of economicdevelopment takings is a recently developed euphemism for the broad exercise of government power, cloaked in the Fifth Amendment's Takings Clause. ${ }^{9}$

Central to understanding the Takings Clause is the public use restriction - the requirement that when government takes private property, it is for a public use. ${ }^{10}$ The public use restriction, which includes taking private property and transferring it to another private owner for economicdevelopment purposes, has been historically constrained to instances in which the public had a right of use. ${ }^{11}$ But the key word is "use," and that is where Kelo comes in.

According to Justice Stevens, writing for a 5-4 majority in Kelo, the Supreme Court first embraced public use broadly to include public purpos$e s$ at the end of the nineteenth century when it began applying the Fifth Amendment to the states. ${ }^{12}$ Justice Stevens cites to the Court's decision in Fallbrook Irrigation District v. Bradley ${ }^{13}$ for support. Interestingly, this is

2016) (“This is why many people are frustrated and disappointed with our political system. Instead of a democracy where all citizens have an equal say in the governing process, some organizations and individuals have a disproportionate and unfair influence over what the government does. The result is that the power and greed of the few too often win out over the needs of the many.”).

5 Kelo, 545 U.S. at 521 (Thomas, J., dissenting) (“Allowing the government to take property solely for public purposes is bad enough, but extending the concept of public purpose to encompass any economically beneficial goal guarantees that these losses will fall disproportionately on poor communities. Those communities are not only systematically less likely to put their lands to the highest and best social use, but are also the least politically powerful.”); Somin, supra note 2, at 101; Carpenter \& Ross, supra note 1 , at 2455-57.

6545 U.S. 469 (2005).

7 Id. at 479 .

8 Id. at 491 (Kennedy, J., concurring) (quoting Kelo v. City of New London, No. 557299, 2002 WL 500238, at *36 (Conn. Super. Ct. Mar. 13, 2002), aff'd in part, rev'd in part, 843 A.2d 500 (Conn. 2004), aff'd, 545 U.S. 469 (2005)).

9 Brown, supra note 1 , at 150.

10 U.S. CONST. amend. V ("No person shall be ... deprived of life, liberty, or property, without due process of law; nor shall private property be taken for public use, without just compensation.”).

11 See Kelo, 545 U.S. at 511-13 (Thomas, J., dissenting) (discussing early uses of the eminent domain power under the Mill Acts as support for government authority to take under the Fifth Amendment only if the public or the government actually uses the property taken).

12 Id. at 479-80 (citing Fallbrook Irrigation Dist. v. Bradley, 164 U.S. 112, 158-64 (1896)).

13164 U.S. 112 (1896). 
the same Court that decided the infamous Plessy v. Ferguson, ${ }^{14}$ which gave legal sanction to the majoritarian view of the time that separate but equal public accommodations passed constitutional muster. ${ }^{15}$

After this shift from public use to public purpose, the Court continued on a path of ever-expanding interpretation of public purpose. ${ }^{16}$ Eventually, in Kelo, the Court permitted use of eminent domain for economic development. According to this broad view of public purpose, transferring property from one private party to another in order to create jobs, increase tax revenue, and revitalize communities are all public purposes, "reflecting [the Court's] longstanding policy of deference to legislative judgments in this field." ${ }^{17}$

In contrast, Justice Thomas dissented in Kelo, cautioning against the majority's limitless approach to the limitations imposed by the Public Use Clause on government's ability to exercise its eminent-domain power. ${ }^{18}$ Justice Thomas had the unfortunate truth of the vastly disparate uses of eminent domain clearly in sight when he cautioned for a narrow understanding of public use, supported by state limits on the exercise of eminent domain relating back to the early Mill Acts ${ }^{19}$ at the time of the country's founding. ${ }^{20}$ Less deference to legislative prerogatives, more adherence to original meaning-namely, more fairness and security for vulnerable groups - these are themes that can be drawn from Justice Thomas's Kelo dissent.

This Essay submits that the arguments that Justice Thomas constructed in his dissent were appropriately focused on the inherently political nature of the Fifth Amendment's Public Use Clause. Unlike the majority, Justice Thomas recognized that when the Supreme Court broadly interprets the public use restriction of the Fifth Amendment's Takings Clause, and at the same time defers to political actors in this arena, it fundamentally abdicates

\footnotetext{
14163 U.S. 537 (1896), overruled by Brown v. Bd. of Educ., 347 U.S. 483, 495 (1954).

15 Id. at 550-51; Brad Snyder, What Would Justice Holmes Do (WWJHD)?: Rehnquist's Plessy Memo, Majoritarianism, and Parents Involved, 69 Оніо Sт. L.J. 873, 875, 898 (2008).

16 Compare Haw. Hous. Auth. v. Midkiff, 467 U.S. 229, 231-32 (1984) (upholding the use of eminent domain for purposes of land distribution), and Berman v. Parker, 348 U.S. 26, 34-35 (1954) (upholding the use of eminent domain to condemn properties for slum clearance), with Kelo, 545 U.S. at 500-501 (O’Connor, J., dissenting) (distinguishing the removal of harmful property use to achieve direct public benefit from the removal of Kelo's "well-maintained home," which was not the source of any social harm).

17 Kelo, 545 U.S. at 480.

18 Id. at 521-22 (Thomas, J., dissenting).

19 See Dennis Bechara, Eminent Domain and the Rule of Law, 35 FreEman 273, 277 (1985) (explaining that the Mill Acts were statutes enacted by twenty-nine states by 1884, which established restraint-free mechanisms for establishing mills).

20 Kelo, 545 U.S. at 512-13 (Thomas, J., dissenting); David M. Gold, Eminent Domain and Economic Development: The Mill Acts and the Origins of Laissez-Faire Constitutionalism, $21 \mathrm{~J}$. LiBerTARIAN STUD. 101, 101 (2007). See generally Abram P. Staples, The Mill Acts, 9 VA. L. Reg. 265 (1903) (defining the Mill Act statutes of the several states and their purposes).
} 
its constitutional responsibility. ${ }^{21}$ By deferring to political actors in this area, the Court in Kelo fundamentally abdicated its responsibility and also adopted a majoritarian doctrinal approach. Further, the Court conflated political ends with constitutional purposes. And it is for this crucial reason that the Fifth Amendment aims to insert a check on majoritarian power through express limitations on government's exercise of eminent domain as expressed in the Takings Clause of the Fifth Amendment. ${ }^{22}$

This Essay first discusses the underlying facts of the Kelo decision and lays a foundation for understanding the intensely political nature of the decision to take private property for economic development in the Fort Trumbull area of New London, Connecticut. Second, it explores the Kelo Court's close hewing to majoritarian views in the realm of the Fifth Amendment's Public Use Clause. It also explains the inherently political DNA that courses through the majority's public use test and why it is dangerous. Finally, this Essay addresses the holdout dilemma raised by many scholars in support of the Kelo majority and offers a solution that addresses holdouts while remaining true to the original meaning of the Public Use Clause as eloquently expressed by Justice Thomas.

\section{KELO: A FAILURE IN POLITICAL JUDGMENT}

The transfer of property from one private owner to another for economic development has always worked to disadvantage historically underprivileged groups (e.g., minorities, the poor, and the elderly) more than others. ${ }^{23}$ And, as the NAACP argued in its Kelo brief, "it is not simply that the exercise of eminent domain, particularly when the purpose is 'economic development,' affects the elderly, minorities, and the economically disadvantaged more often than it does those with more political and economic power, but that it affects those groups in different and more profound ways." ${ }^{24}$ Such was the case in Kelo. Numerous parties wielded political influence that ultimately led to the exercise of eminent domain for economic development in New London, Connecticut. This Part tells the story of the exercise of political power and judgment in the eminent-domain context in Kelo.

\footnotetext{
21 Kelo, 545 U.S. at 514-15 (Thomas, J., dissenting).

22 Id. at 506 (stating that the Public Use Clause of the Fifth Amendment, "originally understood, is a meaningful limit on the government's eminent domain power").

23 See, e.g., Poletown Neighborhood Council v. City of Detroit, 304 N.W.2d 455, 470-71 (Mich. 1981) (per curiam) (Ryan, J., dissenting), overruled by Cty. of Wayne v. Hathcock, 684 N.W.2d 765, 787 (Mich. 2004); Brief of Amici Curiae NAACP et al. in Support of Petitioners, supra note 1, at 10 (providing statistics for economic-development takings that demonstrate the disproportionate impacts on racial and ethnic minorities and the elderly); Carpenter \& Ross, supra note 1, at 2448-49.

24 Brief of Amici Curiae NAACP et al. in Support of Petitioners, supra note 1, at 12.
} 
The City of New London, a waterfront community with a population of approximately 25,000, faced big-city problems in the years leading up to Kelo. ${ }^{25}$ A study prepared for The American Assembly reported:

\begin{abstract}
The poorest residents of southern New London County were concentrated in New London. Unemployment was twice the state average and over half of the New London High School students left before graduation. With just 5.6 square miles of area, New London was also hampered in raising tax revenues because an unusually high proportion (54\%) of city land and buildings were tax exempt. ${ }^{26}$
\end{abstract}

Various parties influenced the legislative outcomes that gave rise to the development plan that resulted in targeting New London for economic development, specifically its historic Fort Trumbull area. ${ }^{27}$ Former Republican Governor John G. Rowland hoped to expand his political base and perhaps his legacy by promoting economic development in the City of New London, which was run by a Democratic city government. ${ }^{28}$ Governor Rowland's administration helped to resuscitate the dormant New London Development Corporation (“NLDC”), a private nonprofit corporation established to assist New London with economic development. ${ }^{29}$ Governor Rowland hoped to use state "revenue surpluses" created by the strong state economy in 1997 to help "catalyze" the struggling economies of Connecticut's heavily democratic cities. ${ }^{30}$ One researcher stated the matter this way:

25 Kelo, 545 U.S. at 473; Eric Rutkow, Kelo v. City of New London, 30 HarV. EnVTL. L. ReV. 261, 261 (2006); Peggy Cosgrove, New London Development Corporation Case Study, Prepared for The Am. Assembly at Columbia Univ. (undated), available at http://www.clairegaudiani.com/ Writings/Writings\%20PDFs/Economic\%20Development\%20PDFs/New\%20London\%20Development \%20Corporation\%20Case\%20Study.pdf.

26 Cosgrove, supra note 25.

27 Maximilian Tondro, The Baltimore Development Corporation: A Case Study of Economic Development Corporations, Shadow Government, and the Fight for Public Transparency and Accountability 8-9 (Dec. 2010) (unpublished independent study, University of Maryland), http://digitalcommons.law.umaryland.edu/cgi/viewcontent.cgi?article=1021\&context=mlh_pubs. Tondro analyzes the decision-making process in Kelo, stating that the belief by the United States Supreme Court that

the municipal government had significant control over the redevelopment project or its implementation, contrasts sharply with the actual interaction between the quasi-public development corporation and the municipal government. This contrast serves as a point of departure to explore the court's problematic reliance on the formal approval by the municipal government of the redevelopment project drawn up and implemented by the development corporation as rendering the project a sufficiently "public purpose" to justify the use of eminent domain delegated to the development corporation. Id. at 2.

28 See, e.g., id. at 8; see also David Collins, John Rowland Changed New London, THE DAY (Feb. 19, 2014), http://www.theday.com/article/20140219/NWS05/302199934. The former governor went to prison in 2005 on corruption charges. Id.

29 Tondro, supra note 27, at 8.

30 Cosgrove, supra note 25. 
The catalyst for the reactivation [of the NLDC] came not from the City, but instead from the state Commissioner of Economic and Community Development, Peter Ellef, who as political advisor and later co-chief of staff to Governor John Rowland pushed major urban development initiatives in heavily Democratic cities to gain political advantage for the Republican governor in a Democratic state. ${ }^{31}$

The NLDC aggressively moved forward with redevelopment plans. Dr. George M. Milne, Jr., President for Central Research at Pfizer, joined the board of the NLDC and gradually concluded that the Fort Trumbull area would be an ideal location for Pfizer's Global Development Facility. ${ }^{32}$ But convincing Pfizer of the idea would require a compelling and strong plan. Governor Rowland responded with a strong state commitment to bring Pfizer to New London. ${ }^{33}$

The NLDC hired a prominent urban-planning firm "to ensure that the new Pfizer facility, with an investment of $\$ 180$ million in private funds, would be the centerpiece of a concentrated reuse of the Fort Trumbull peninsula, which could also include a hotel, retail space, new housing, and a half-mile long public riverwalk.” ${ }^{34}$ The plan came together in December 1997, and in December 1998, Pfizer's Board of Directors approved a $\$ 300$ million Global Development Facility plan for the Fort Trumbull area of New London to include 600 new jobs, 1,300 existing jobs, and a \$125 million annual payroll by $2002 .{ }^{35}$

The plans to bring Pfizer to Fort Trumbull gained momentum. In 2000, the New London City Council voted 6-1 to approve the Fort Trumbull Municipal Development Plan, designating the NLDC as its development agent in charge of implementation. ${ }^{36}$ Later that same year, Corcoran Jennison, a private firm chosen by the NLDC with public-private development expertise, committed to build research and development offices, a luxury hotel, a townhouse community, and conference and fitness centers on Fort Trumbull. Also, Pfizer announced that the worldwide headquarters for its $\$ 4.5$ billion development and research division would be in New London. ${ }^{37}$ "In addition to creating jobs, generating tax revenue, and helping to 'build momentum for the revitalization of downtown New London,' the plan was also designed to make the City more attractive and to create leisure and recreational opportunities . ...”38

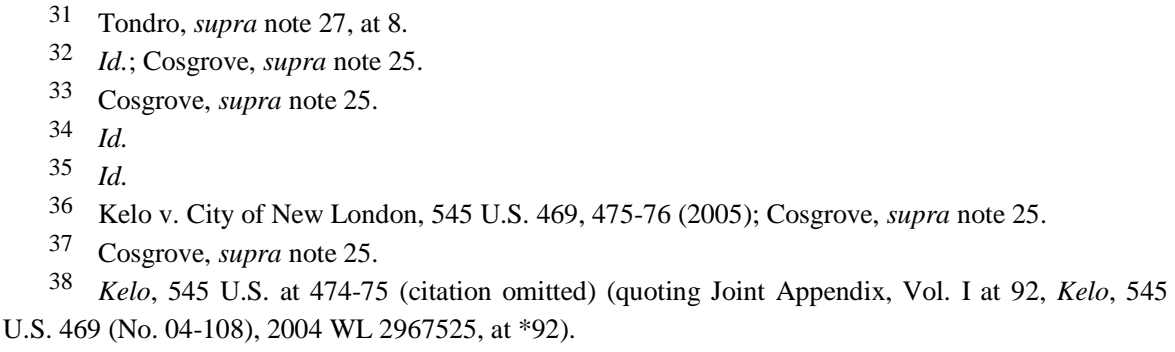


The New London City Council authorized the NLDC to purchase property necessary for the economic-development plan from consenting property owners and to use eminent domain to condemn the property of citizens who hoped to prevent the taking of their property-holdouts. ${ }^{39}$ These "resisting property owners tried to use the political process to prevent the takings" but had "little, if any, hope of prevailing against the vastly more powerful forces arrayed against them" (i.e., Governor Rowland and his administration, state and city leaders, Pfizer, and the NLDC)..$^{40}$

In response to the economic-development plans and the activity of the NLDC, a group of citizens formed the Coalition to Save Fort Trumbull ("Coalition"). But, without the political influence of many of the "movers and shakers" who pushed for the exercise of eminent domain in Fort Trumbull for economic development, the Coalition had nowhere near the impact of those who were more politically connected. ${ }^{41}$ Lloyd Beachy, a New London city councilor who had been critical of the NLDC and of New London's redevelopment projects, often sided with the Coalition in calling for the NLDC to move more slowly on its demolition plans. ${ }^{42}$ In response to the NLDC's announcement that it had decided not to demolish the Italian Dramatic Club, built by Italian immigrants in 1922 and known to have guests who were politically well-connected, ${ }^{43}$ Councilman Beachy explained:

\footnotetext{
“I don't know what it all means, but I see that if you have political connections you can get anything done in this city . . . I'm ecstatic for them but somewhat frustrated as to why those with less power in the community don't get the same consideration. . . . People in the coalition are not the movers and shakers in the community .... . As a result, they don't have the same kind of impact." 44
}

And, at the same time, City Councilor Rob Pero agreed that it could appear that the Italian Dramatic Club was spared by the NLDC because many of its supporters were politically well-connected. ${ }^{45}$ Susette Kelo, a working-class homeowner who fought a losing battle to keep her home, hoped the NLDC's decision to save the Italian Dramatic Club signaled that

\footnotetext{
39 Id. at 475.

40 Ilya Somin, The Story Behind Kelo v. City of New London-How an Obscure Takings Case Got to the Supreme Court and Shocked the Nation, WASH. Post (May 29, 2015), https://www. washingtonpost.com/news/volokh-conspiracy/wp/2015/05/29/the-story-behind-the-kelo-case-how-anobscure-takings-case-came-to-shock-the-conscience-of-the-nation/.

41 Kathleen Edgecomb, Decision to Save Italian Club Questioned, THE DAY (Sept. 21, 2000), http://www.theday.com/article/20000921/DAYARC/309219943/0/Search.

42 Id.

43 Id. ("Months into an urban renewal plan that is changing the landscape in parts of the city, the club may be the only surviving structure from a long-forgotten Italian neighborhood in the city's Fort Trumbull peninsula.”).

44 Id.

45 Id.
} 
a door to meaningful discussions had opened. ${ }^{46}$ Other property owners targeted for eminent domain were not so optimistic. But in the end, once state and local leaders determined that Pfizer could make better use of the targeted Fort Trumbull properties than their owners, the political and economic forces behind these "movers and shakers" were too much for Ms. Kelo and her neighbors to overcome. ${ }^{47}$

Many local actors, including affected Fort Trumbull property owners, perceived that the decision to use eminent domain to take private property for economic development was politically motivated or, at the very least, that the majority who supported the plan, many of whom were politically connected and powerful, were dictating the results. ${ }^{48}$ Ultimately, however, the decision to destroy neighborhoods for economic development did not yield nearly the promised public benefits, prompting Connecticut Supreme Court Justice Richard Palmer, one of four justices who voted with the 4-3 majority against Ms. Kelo, to apologize to her years later. ${ }^{49}$ Justice Palmer wrote that his apology to Ms. Kelo was predicated on facts that he could not have not have known until after the Connecticut Supreme Court's decision because they were not in existence at the time- “" "namely, that the city's development plan had never materialized and, as a result, years later, the land at issue remains barren and wholly undeveloped." 50 For all that the government took, the return was urban blight; the land seized by eminent domain sits vacant. ${ }^{51}$

The Kelo decision intensified the debate about the extent to which property rights should receive constitutional protection from majoritarian influences-political institutions and state legislative bodies-that hold private-property rights protected by the United States Constitution in low regard. ${ }^{52}$ Next, Part II turns to this discussion.

46 Id.

47 See Edgecomb, supra note 41; see also JAMEs W. ELY, JR., THE GUARDIAN OF EVERY OTHER Right: A CONSTITUtionAl History OF PROPERTy Rights 157 (3d ed. 2008) ("Under Kelo, legislators appear to hold virtually unlimited power to decide whether eminent domain is appropriate for particular projects.”).

48 Edgecomb, supra note 41.

49 Jeff Benedict, Apology Adds an Epilogue to Kelo Case, HARTFORD CouranT (Sept. 18, 2011), http://articles.courant.com/2011-09-18/news/hc-op-justice-palmer-apology-20110918_1_kelo-caselittle-pink-house-book-editor.

50 Id.

51 Alec Torres, Nine Years After Kelo, the Seized Land Is Empty, NAT’L REV. (Feb. 5, 2014), http://www.nationalreview.com/article/370441/nine-years-after-kelo-seized-land-empty-alec-torres (showing a visual depiction of the Fort Trumbull area today).

52 ELY, supra note 47, at 5, 157. 


\section{THE COUNTERMAJORITARIAN DifFICULTY: THE POLITICAL NATURE OF PUBliC USE AND TAKINGS FOR ECONOMIC DEVELOPMENT}

This Part considers the approaches of the majority and dissenting justices in Kelo, particularly Justice Thomas's dissent, focusing on the Court's majoritarian approach to private-property-rights protection in the area of takings and eminent domain. First, it delineates the importance of property rights for the poor as well as the rich and the role that the Constitution plays in protecting private-property rights. Then, it turns to Justice Thomas's dissent, discussing the benefits of a countermajoritarian judicial force in the American democratic system, as represented by Justice Thomas in Kelo, and why the countermajoritarian difficulty ${ }^{53}$ may not be so difficult in this area of the law.

\section{A. Why Constitutional Protection of Property Rights Is Important}

When one thinks of property rights, one typically focuses on the wealthy protecting their largess. But that is a misconception. ${ }^{54}$ Disadvantaged-even poor-people have real property and, indeed, in the context of eminent domain, these people are the most likely losers because they are the least politically powerful and their property is worth less. ${ }^{55}$ So, in some sense, the poor need the constitutional protections of the Fifth Amendment's Public Use Clause the most because they lack political power and are more likely than the wealthy to be the victims of eminent domain. ${ }^{56}$

Two hundred and forty years ago, Virginia patriot Arthur Lee said, "The right of property is the guardian of every other right, and to deprive a people of this, is in fact to deprive them of their liberty." ${ }^{77}$ The Public Use Clause, like the other provisions of the Bill of Rights, was "designed to limit the scope of majority rule over matters deemed fundamental in a free

\footnotetext{
53 Alexander M. Bickel, The Least Dangerous Branch: The Supreme Court at the Bar OF Politics 16 (2d ed. 1962). This phrase is attributed to Mr. Bickel who introduced it in his book.

54 Kelo v. City of New London, 545 U.S. 469, 521-22 (2005) (Thomas, J., dissenting).

55 Id.; Brief of Amici Curiae NAACP et al. in Support of Petitioners, supra note 1, at 11-14 ("The reason these groups are disproportionately affected is that they are palatable political and economic targets. Condemnations in predominately minority or elderly neighborhoods are often easier to accomplish because these groups are less likely, or often unable, to contest the action. ... The fact that particular property is identified and designated for 'economic development,' however, almost certainly means that the market is currently undervaluing that property or that the property has some 'trapped' value that the market is not currently recognizing. . . . Because the neighborhoods chosen are (in large part) selected because of the low market value of the properties therein, these displaced individuals will typically have a difficult time finding adequate replacement housing.”).

56 Brief of Amici Curiae NAACP et al. in Support of Petitioners, supra note 1, at 11.

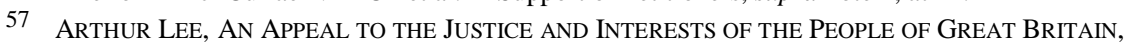
IN THE PRESENT Disputes WiTH AMERICA 14 (London, Robson, Angus, \& Co., 4th ed. 1776).
} 
society." ${ }^{58}$ And the Founders viewed private-property protections as fundamental to liberty. ${ }^{59}$ After Kelo, the ability of government to take private property expanded exponentially because of a "jettisoning" of historic constitutional limitations on the exercise of governments' power to take private property. ${ }^{60}$ Constitutional limitations can easily be amended - the rules of the game of politics changed-when these restraints and commitments to protect the interests of the politically and economically disadvantaged against majority interests fail. ${ }^{61}$

The Kelo majority's approach to the Public Use Clause was explicitly majoritarian. The Court used "the prevailing position of state legislaturesits proxy for the will of the people-to delineate the contours of constitutional law." ${ }^{62}$ At the heart of the sharply divided Kelo decision is the reality of structural inequalities that are inextricably present when the judiciary allows the majority to exercise the power of law against dissenters (or holdouts). ${ }^{63}$ The public use requirement for the exercise of eminent domain generates debate because it does not have a fixed, accepted meaning. Kelo highlights this point - the case's entire outcome turns on what constitutes a public use, understood to include public purposes. ${ }^{64}$

Practically all cities, New London included, are laboratories of competing interests. Early uses of eminent domain were for common carriers and other public and quasi-public projects like highways, mills, manufactories, and public utilities. ${ }^{65}$ Justice Stevens and scholars sympathetic to a broad construction of the public use restriction point to these early uses of eminent domain by the states to support their positions. Justice Stevens

\footnotetext{
58 ELY, supra note 47, at 4 .

59 Kelo, 545 U.S. at 505 (O’Connor, J., dissenting) (“Any property may now be taken for the benefit of another private party, but the fallout from this decision will not be random. The beneficiaries are likely to be those citizens with disproportionate influence and power in the political process, including large corporations and development firms. As for the victims, the government now has license to transfer property from those with fewer resources to those with more. The Founders cannot have intended this perverse result. '[T]hat alone is a just government,' wrote James Madison, 'which impartially secures to every man, whatever is his own." (quoting James Madison, Property, NAT’L GAZETTE, Mar. 27, 1792, reprinted in 14 THE PAPERS OF JAMES MADISON 266 (Robert A. Rutland et al. eds., 1983))).

60 Gideon Kanner, Kelo v. New London: Bad Law, Bad Policy, and Bad Judgment, 38 URB. LAW. 201, 202 (2006).

61 See Mila Versteeg, The Politics of Takings Clauses, 109 Nw. U. L. REv. 695, 702 (2015).

62 Corinna Barrett Lain, The Doctrinal Side of Majority Will, 2010 Mich. ST. L. REV. 775, 776 (footnote omitted); see Kelo, 545 U.S. at 480 (discussing judicial deference to legislative judgments in the field of takings).

63 Laura S. Underkuffler, Kelo’s Moral Failure, 15 WM. \& MARY BILL RTs. J. 377, 378 (2006).

64 Kelo, 545 U.S. at 480 ("The disposition of this case ... turns on the question whether the City's development plan serves a 'public purpose.'”).

65 Id. at 512 (Thomas, J., dissenting) (discussing the early Mill Acts); ELY, supra note 47, at 77 (discussing the states' aggressive use of eminent domain in the 1800s to promote transportation projects); John Fee, Reforming Eminent Domain, in EMINENT DomAin USE AND ABUSE: KELO IN CONTEXT 125, 129 (Dwight H. Merriam \& Mary Massaron Ross eds. 2006).
} 
wrote in Kelo that many state courts circumvented or completely abandoned the “'use by the public' test” by authorizing Mill Acts ${ }^{66}$ that allowed manufacturers to flood private upstream lands. ${ }^{67}$ Others argue that, in the early nineteenth and twentieth centuries, states permitted private entrepreneurs to acquire property through the exercise of eminent domain based upon anticipated public benefits resulting from the forced transfers. ${ }^{68}$

But some scholars and jurists, like Justice Thomas, take issue with this characterization of the Mill Acts and these early exercises of eminent domain. ${ }^{69}$ According to them, gristmills "were America's first businesses 'affected with pubic interest"” and, thus, there is something "poignant about the suggestion that gristmills might not be public institutions." in Head v. Amoskeag Manufacturing Co. ${ }^{71}$ stated,

The principle objects, no doubt, of the earlier [general mill] acts were grist mills; and it has been generally admitted, even by those courts which have entertained the most restricted view of the legislative power, that a grist mill which grinds for all comers, at tolls fixed by law, is for a public use. ${ }^{72}$

And as one scholar remarked, "it is interesting to note that even before it was relevant as a matter of law, some common [colonial] practices, such as those authorized by the Mill Acts, resulted in takings that would satisfy the modern narrow standard." ${ }^{73}$ As for practices that would only be countenanced under a much broader standard of public use or public purpose, in 1848 in West River Bridge Co. v. Dix ${ }^{74}$ Daniel Webster unsuccessfully argued before the Supreme Court for strong federal court supervision over eminent domain by the states. Against eminent domain, he pled:

[O]ur only security is to be found in this tribunal, to keep it within some safe and welldefined limits, or our State governments will be but unlimited despotisms over the private citizens. They will soon resolve themselves into the existing will of the existing majority, as

66 Head v. Amoskeag Mfg. Co., 113 U.S. 9, 16-18 (1885) (providing a comprehensive listing of the early Mill Acts statutes by states).

67 Kelo, 545 U.S. at 479 n.8.

68 See ELY, supra note 47, at 93-94, 129.

69 Kelo, 545 U.S. at 512-15 (Thomas, J., dissenting) (discussing the early Mill Acts).

70 Gold, supra note 20, at 117.

71113 U.S. 9 (1885).

72 Id. at $18-19$.

73 Charles E. Cohen, Eminent Domain After Kelo v. City of New London: An Argument for Banning Economic Development Takings, 29 HARV. J.L. \& PUB. POL'Y 491, 503 (2006).

7447 U.S. (6 How.) 507 (1848). In 1795, the State of Vermont granted the West River Bridge Company a 100-year franchise to build and operate a toll bridge over West River. Then, in 1843, a Vermont State court ordered that the bridge could be taken by eminent domain for free public travel with $\$ 4,000$ in compensation paid to the owners. Id. at 511-14. This case is described as the first Supreme Court case addressing the states' eminent domain power. E.g., Leslie Bender, The Takings Clause: Principles or Politics?, 34 Buff. L. Rev. 735, 761 (1985). 
to what shall be taken, and what shall be left to any obnoxious natural or artificial person. It is easy to see, that, by a very slight improvement on the proceedings in this case, and in pursuance of the avowed principle, that, as to the exercise of this power of eminent domain, the legislature, or their agents, are to be the sole judges of what is to be taken, and to what public use it is to be appropriated, the most levelling ultraisms of Antirentism or agrarianism or Abolitionism may be successfully advanced. ${ }^{75}$

Also, those who support strict requirements on public use emphasize that it is a legal anachronism to compare historic exercises of eminent domain with eminent domain used for economic development because many of the nineteenth and early twentieth century takings involved rural, vacant land. ${ }^{76}$ In contrast, many modern economic-development takings, like Kelo, result in the demolition of densely populated, urban residences and the displacement of massive numbers of inhabitants from their businesses and homes. ${ }^{77}$

The arguments of Justices Stevens and Thomas begin at different starting points. Imagine a race track. Justice Stevens's starting point is already half way towards finding economic-development takings to be within the definition of public use. In this area, the Court seems to view its proper function as a majoritarian institution, protecting the interests of states and localities because these institutions believe economic-development takings will contribute to long-term economic development and growth, which inure to the benefits of the broader population. ${ }^{78}$

It would appear that Justice Stevens believes that, because the Court broadly interpreted public use to include public purposes at the end of the nineteenth century, that should be the starting point for the Kelo argument. ${ }^{79}$ In making the case for a judicial precedent that has historically embraced a broad understanding of public purpose, Justice Stevens discusses changing societal circumstances and evolving societal needs. He argues that these changing circumstances and evolving needs justify continuing to adhere to more than a century of public use jurisprudence that, according to Justice Stevens, "has wisely eschewed rigid formulas and intrusive scrutiny in favor of affording legislatures broad latitude in determining what public needs justify the use of the takings power." ${ }^{80}$ Justice Stevens is comfortable deferring to legislatures and appropriating authorities to structure the definition of public purpose, with minimal conditions. ${ }^{81}$ But leaving this freedom

75 Dix, 47 U.S. (6 How.) at 520-21.

76 Kanner, supra note 60, at 206.

77 Id.

78 See Kelo v. City of New London, 545 U.S. 469, 480 (2005). See generally Versteeg, supra note 61, at 704 (discussing whether constitutional takings clauses are majoritarian).

79 Kelo, 545 U.S. at 479-80.

80 Id. at 483.

81 Id. at 484 ("Given the comprehensive character of the plan, the thorough deliberation that preceded its adoption, and the limited scope of our review, it is appropriate for us, as it was in Berman, to resolve the challenges of the individual owners, not on a piecemeal basis, but rather in light of the 
to legislatures and appropriating authorities works to decrease the legal certainty and constitutional protection that the public purpose requirement provides. $^{82}$

The Kelo majority's decision to leave the shaping of the understanding of public purpose to the legislatures and various appropriating authorities, noting that states remain free to impose further restrictions on the takings power and the exercise of eminent domain, is a view that resonates among some advocates of broadly construed eminent domain authority. ${ }^{83}$ Professor John D. Echeverria testified before Congress that the Supreme Court was wise to leave broad discretion with state and local governments on when and how to use eminent domain for economic development. ${ }^{84} \mathrm{He}$ and others observe that more than forty states responded to the Kelo decision with some degree of post-Kelo-reform legislation and some state supreme courts have interpreted their state takings clauses to prohibit economicdevelopment takings. ${ }^{85}$ As Professor Echeverria testified:

The bottom line is that different states have adopted different positions that reflect the values and preferences of their citizens and the relative need for eminent domain as a tool for urban revitalization in each state. As the founding fathers intended, the states are not only charting

entire plan. Because that plan unquestionably serves a public purpose, the takings challenged here satisfy the public use requirement of the Fifth Amendment.”).

82 Björn Hoops, The Public Purpose for the Expropriation of Land: A Framework for Assessing Its Democratic Legitimacy 4 (Jan. 4, 2014) (unpublished manuscript), http://ssrn.com/ abstract $=2539026$.

83 Kelo, 545 U.S. at 489; State of Property Rights in America Ten Years After Kelo v. City of New London: Hearing Before the Subcomm. on the Constitution and Civil Justice of the H. Comm. on the Judiciary, 114th Cong. 41 (2015) (testimony of John D. Echeverria, Professor of Law, Vermont Law School) [hereinafter Echeverria], http://judiciary.house.gov/index.cfm?a=Files.Serve\&File_id= F9CEA8D7-C974-4A97-B828-A9D5B9E14C36.

84 Echeverria, supra note 83, at 40.

85 Id. at 41; see also Eminent Domain Overview, NAT'L CONFEREnCE STATE LEgISLATURES, http://tinyurl.com/mpph7bf (last visited Jan. 10, 2016). See generally Ilya Somin, The Limits of Backlash: Assessing the Political Response to Kelo, 93 MinN. L. REV. 2100, 2114-16 (2009) (writing from the property-owner perspective that economic-development, or person-to-person, condemnations should be stopped and analyzing the post-Kelo enactments as "effective" or "ineffective"). Professor Somin states that statutes are said to be effective if "they provide property owners with at least some significant protection against economic-development condemnations beyond that available under preexisting law" whereas statutes are said to be ineffective "if they forbid economic-development condemnations but essentially allow them to continue under another name,” such as through a loose definition of "blight.” Id. at 2114. Applying these standards, Professor Somin finds that twenty states have enacted effective reforms either through state legislation, citizen-initiated referenda, or legislature-initiated referenda, while twenty-six states have enacted reforms that are ineffective — one by citizen-initiated referendum and the rest by one of the legislative actions. Id. at 2115. The major loopholes in the ineffective statutes, according to Professor Somin, are loose definitions of "blight" that include areas that contain "obstacle[s] to 'sound growth"” or conditions that constitute an “'economic or social liability."” Id. at 2122. This criticism extends to popular "blight” definition phrases, such as: “'a menace to the public health, safety, morals, or welfare[]' . . . because almost any condition that impedes economic development could be considered a 'menace to the public ... welfare.'” Id. at 2122-24 \& nn.88-97. 
their own paths but they are serving as the laboratories of democracy, testing different approaches to the use (and non-use) of eminent domain. ${ }^{86}$

But this argument by the Kelo majority and its supporters ignores important facts about the U.S. Constitution and the workings of the United States' democratic system, not to mention important realities about the economic consequences of economic-development takings. First, enforcing the Constitution should take precedence over the policies and preferences of states and localities. Justice O’Connor, who was joined in her Kelo dissent by Chief Justice Roberts and Justices Scalia and Thomas, aptly captured the appropriate role of judicial deference to the Constitution:

[T]he Court suggests that property owners should turn to the States, who may or may not choose to impose appropriate limits on economic development takings. This is an abdication of our responsibility. States play many important functions in our system of dual sovereignty, but compensating for our refusal to enforce properly the Federal Constitution (and a provision meant to curtail state action, no less) is not among them. ${ }^{87}$

Second, federal courts are not bound by state legislative and judicial pronouncements on the meaning of public use or public purpose. ${ }^{88}$ In other words, state statutory and judicial standards will dictate what constitutes property under their state systems, but states cannot transform their standards into federal constitutional standards. ${ }^{89}$ Finally, a majoritarian approach to judicial decisionmaking in this area of economic-development takings is

86 Echeverria, supra note 83, at 41-42.

87 Kelo, 545 U.S. at 504 (O’Connor, J., dissenting) (citation omitted).

88 Id. at 517-18 (Thomas, J., dissenting) (“[A] court owes no deference to a legislature's judgment concerning the quintessentially legal question of whether the government owns, or the public has a legal right to use, the taken property.”).

89 Whittaker v. Cty. of Lawrence, 674 F. Supp. 2d 668, 689-90 (W.D. Pa. 2009), aff'd, 437 F. App’x 105 (3d Cir. 2011). As the court in Whittaker explained:

States are undoubtedly free to create "public use" standards that are more demanding than that contained in the Fifth Amendment. Pennsylvania has done just that. Indeed, subsequent to the Supreme Court's decision in Kelo, the Pennsylvania Legislature passed legislation generally prohibiting the use of eminent domain power for the purpose of facilitating "private enterprise." It does not follow, however, that actions taken in contravention of such state proscriptions are likewise taken in contravention of the Public Use Clause. The content of the Public Use Clause does not "vary from place to place and from time to time." The "public use” requirement is "coterminous with the scope of a sovereign's police powers." It does not change based on how a particular sovereign chooses to use (or not use) its police powers. As far as the United States Constitution is concerned, a "public use” in Connecticut is a "public use” in Pennsylvania. The Plaintiffs attempt to convert state statutory standards into federal constitutional requirements, "[b]ut constitutional law does not work that way." If the Plaintiffs' argument were to be accepted, every taking effectuated for a "purpose" proscribed by state law would be transformed into a federal constitutional violation. The reasoning employed by the Supreme Court in ... Kelo does not countenance such a result.

Id. (footnote omitted) (citations omitted) (quoting Whren v. United States, 517 U.S. 806, 815 (1996); Cruzan v. Dir., Mo. Dep’t of Health, 497 U.S. 261, 286 (1990); Haw. Hous. Auth. v. Midkiff, 467 U.S. 229, 240 (1984)). 
severely undermined by the evidence that, most often, the kinds of economic-development takings like the one in Kelo that led Justice Stevens to hold that it "unquestionably serves a public purpose" ${ }^{90}$ do not yield the positive fiscal impacts that are touted in order to induce states to exercise eminent domain. ${ }^{91}$ In 2014, economists Carrie B. Kerekes and Dean Stansel reported that their research found no statistically significant correlation between state and local tax revenue levels and eminent domain..$^{92}$ To the contrary, they documented a significantly negative relationship between future state and local tax revenue growth and eminent domain..$^{93}$

Equipped with an understanding of why constitutional protection is particularly important to the disadvantaged in the eminent domain context, this Essay now focuses on Justice Thomas and his dissent in Kelo.

\section{B. Justice Thomas's Kelo Dissent}

Justice Thomas joined Justice O'Connor's principal dissent and also authored a compelling dissent of his own, in which he took a countermajoritarian approach to judicial review of the Public Use Clause and argued for an originalist interpretation. ${ }^{94}$ Justice Thomas's dissent was consistent with what seems to be his judicial philosophy that the judiciary should "scrape off misguided precedent, however venerable." ${ }^{95}$ And, in fact, Justice Thomas is a frequent dissenter, having dissented, in whole or in part, in more than 54 percent of the Supreme Court cases in which he has participated. ${ }^{96}$

Justice Thomas's starting point is rooted in the Constitution and his understanding of the original intent of the Fifth Amendment as a check on governmental power. ${ }^{97}$ Unlike the majority, he does not begin by focusing on the legislature or the popular will; rather, he employs a starkly counter-

\footnotetext{
90 Kelo, 545 U.S. at 484.

91 Carrie B. Kerekes \& Dean Stansel, Takings and Tax Revenue: Fiscal Impacts of Eminent Domain 4-5, 35-36 (George Mason Univ. Mercatus Ctr. Working Paper, 2014), http://mercatus.org/sites/ default/files/Kerekes-Eminent-Domain.pdf.

92 Id. at 5.

93 Id.

94 Kelo, 545 U.S. at 506 (Thomas, J., dissenting) (stating that the decision ignores “original meaning” and renders "the Public Use Clause to be a virtual nullity”).

95 Ralph A. Rossum, Understanding Clarence ThOMAs: The Jurisprudence OF CONSTITUTIONAL RESTORATION 134 (2014).

96 Writings by Justice Thomas, CORNELL LEGAL INFO. INST., https://www.law.cornell.edu/ supct/author.php?thomas (last visited Jan. 10, 2016). One scholar describes the American dissenter (generally speaking) as a "nonconformist" who bears "the scorn of the herd whose collective thinking he challenges. He is the heretic whose heresy may not stand the rays of established thought or the spectrum of time. Or he may be the prophet whose heresy of today becomes the dogma of tomorrow." PERCIVAL E. JACKSON, Dissent in THE Supreme Court: A CHRONOLOGY 3 (1969).

97 Kelo, 545 U.S. at 506-07 (Thomas, J., dissenting).
} 
majoritarian approach. ${ }^{98}$ Justice Thomas supports his narrow interpretation of the Public Use Clause with a historic reading of the text of the Public Use Clause as a prohibition on government exercise of power and not a grant of power. ${ }^{99}$ Further, he is not wedded to the pronouncements of the nineteenth century Supreme Court on the meaning of public use in the Takings Clause. ${ }^{100} \mathrm{He}$ writes that, "without the slightest nod to its original meaning[,]" the Court continues on a path of eviscerating the efficacy of the Public Use Clause as a meaningful limitation on the exercise of the power of eminent domain by the government. ${ }^{101}$ Justice Thomas would have the Court "reconsider" all of these cases which he believes have misconstrued the Public Use Clause and, in so doing, limited the efficacy of the Supreme Court as a bulwark against majoritarian abuses of power.

Many people speak of private-property rights as though they are a hindrance to poor people, and private-property-rights advocates are often villainized and blamed for many of the social ills of the past, including racial inequality, social injustices, and poverty. Critics of private-property-rights advocates argue that the work of these individuals inevitably ends up supporting the wealthy and corporate-property rights.

In his Kelo dissent, Justice Thomas draws a stark contrast to this negative view of private-property rights. According to his contrasting view, a robust system of private-property rights and protections is essential to the establishment and maintenance of functioning democracies and markets, as well as individual liberty. He writes:

The consequences of today's decision are not difficult to predict, and promise to be harmful.
So-called "urban renewal” programs provide some compensation for the properties they take,
but no compensation is possible for the subjective value of these lands to the individuals dis-
placed and the indignity inflicted by uprooting them from their homes. Allowing the gov-
ernment to take property solely for public purposes is bad enough, but extending the concept
of public purpose to encompass any economically beneficial goal guarantees that these losses
will fall disproportionately on poor communities. Those communities are not only systemati-
cally less likely to put their lands to the highest and best social use, but are also the least po-
litically powerful. If ever there were justification for intrusive judicial review of constitution-
al provisions that protect "discrete and insular minorities," surely that principle would apply
with great force to the powerless groups and individuals the Public Use Clause protects. The
deferential standard this Court has adopted for the Public Use Clause is therefore deeply per-
verse. It encourages "those citizens with disproportionate influence and power in the political
process, including large corporations and development firms," to victimize the weak. ${ }^{102}$

At its core, Justice Thomas's Kelo dissent may be understood as an expression of concern about a "public interest" test inherent in the Kelo

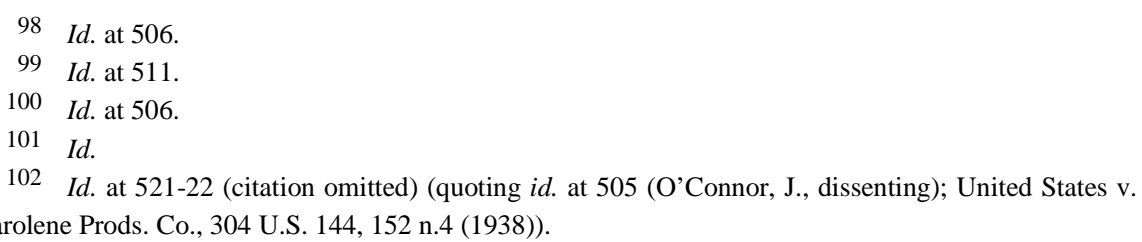


decision. ${ }^{103}$ He argues that, if we depart from the natural meaning and understanding of "public use" and substitute other concepts like public interest, then "we are afloat without any certain principle to guide us." ${ }^{104}$ And, if there is not a dime's worth of difference between public interest and political interest - which is determined in the arena of politics - then, in many ways, Kelo is tethered to an accordion notion of the role of government. The United States is presently in an environment of an expanding notion of what government should and ought to be providing, and, in Kelo, the Court is the accordion player. ${ }^{105}$ As Justice O'Connor aptly stated in her Kelo dissent, joined by Justice Thomas,

\begin{abstract}
If legislative prognostications about the secondary public benefits of a new use can legitimate a taking, there is nothing in the Court's rule ... to prohibit property transfers generated with less care, that are less comprehensive, that happen to result from less elaborate process, whose only projected advantage is the incidence of higher taxes, or that hope to transform an already prosperous city into an even more prosperous one. ${ }^{106}$
\end{abstract}

\title{
III. HOLDiNG OUT AND HOLDING ON
}

Kelo certainly was not the first decision that can be questioned on the ground that it permitted the takings of the homes of poor-and-middle-class citizens and subsequent transfer to the wealthy-all in the name of economic development. ${ }^{107}$ Poletown Neighborhood Council v. City of Detroit ${ }^{108}$ is

\footnotetext{
103 Kelo, 545 U.S. at 520 (Thomas, J., dissenting).

104 Id. (quoting Bloodgood v. Mohawk \& Hudson R.R., 18 Wend. 9, 61 (N.Y. 1837) (opinion of Tracy, Sen.)) (internal quotation marks omitted).

105 Michael Schuyler, A Short History of Government Taxing and Spending in the United States,
} TAX Found (Feb. 19, 2014), http://taxfoundation.org/article/short-history-government-taxing-andspending-united-states (discussing dramatic federal government expansion in the 20th century and continued expansion in the 21st century); Jim VandeHei, Blueprint Calls for Bigger, More Powerful Government, WASH. POST (Feb. 9, 2005), http://www.washingtonpost.com/wp-dyn/articles/A93072005Feb8.html ("President Bush's second-term agenda would expand not only the size of the federal government but also its influence over the lives of millions of Americans by imposing new national restrictions on high schools, court cases and marriages.”); Douglas J. Amy, Why We Need More, Not Less, Government, Gov'T Is GooD, http://www.governmentisgood.com/articles.php?aid=8 (last visited Jan. 10, 2016) ("For decades, conservatives have been pushing for smaller government, and have consistently called for reduced social spending, less regulation, and more tax cuts. But not everyone agrees. When the financial crisis hit in the fall of 2008 and the economy began to melt down, suddenly there were calls for bigger and more active government. Many people wanted a massive federal stimulus plan to ward off an economic depression, and others demanded the widespread re-regulation of financial markets to prevent a recurrence of these problems.”); Bailout Recipients, ProPuBlicA, https://projects.propublica.org/bailout/list (last visited Jan. 10, 2016).

106 Kelo, 545 U.S. at 504 (O’Connor, J., dissenting).

107 Brett D. Liles, Reconsidering Poletown: In the Wake of Kelo, States Should Move to Restore Private Property Rights, 48 ARIz. L. REV. 369, 374-75 (2006). 
an oft-cited example, and one that Justice Thomas used, which highlights the enduring and tragic struggle by poor and minority communities against the majoritarian power. ${ }^{109}$ This Part begins with a discussion of the holdout "problem" that is often cited as support for the use of the taking power and eminent domain for economic development. Next, it evaluates Kelo within the context of the Michigan Supreme Court's decisions in Poletown and County of Wayne v. Hathcock, ${ }^{110}$ the latter in which the court returned to a narrow view of public use under Michigan's constitution-thus reversing its earlier decision in Poletown. ${ }^{111}$ Further, this Part highlights the starkly different outcomes in the Michigan Supreme Court and the United States Supreme Court regarding the viability of economic-development takings. Finally, it emphasizes an important test offered by the Hathcock court to measure the constitutionality of takings for economic development that the United States Supreme Court should have used in Kelo.

\section{A. Holdouts: A False Problem}

One popular justification for a broad construction of the Public Use Clause is that governments need to have latitude to take private property through eminent domain to overcome land ownership fractionation and "holdouts"-private property owners who, in the face of infrastructure and redevelopment projects, refuse to sell. In other words, if land is divided among many owners, redevelopment and infrastructure projects can be thwarted completely or delayed to the point that they become cost prohibitive by owners who either do not want to sell their property at any price or who hope to reap a windfall profit. ${ }^{112}$ Some describe holdouts as a "problem." ${ }^{113}$ Others take an even more uncharitable view of holdouts. Consider what Andrew Alpern, attorney, architect, and architectural historian, and his coauthor Seymour Durst, real estate investor and developer, wrote in their influential book, Holdouts!:

People who are holdouts come in several varieties. Most pathetic is the frightened holdout. The woman who has lived in the same place for fifty years and is panicked by the idea of being uprooted; the father who is worried that no landlord will accept his retarded son . . . .

Then there is the greedy holdout, who thinks that every developer controls a purse of unlimited depth and that no price is too high to demand. ...

108304 N.W.2d 455 (Mich. 1981) (per curiam), overruled by Cty. of Wayne v. Hathcock, 684 N.W.2d 765 (Mich. 2004).

109 Kelo, 545 U.S. at 522 (Thomas J., dissenting); see also POLETOWN LIVES! (Information Factory, Inc. 1982) (documentary film from the perspectives of the Poletown residents who fought the General Motors project that displaced them).

110684 N.W.2d 765 (Mich. 2004).

111 Id. at 787 (overruling Poletown partly “to vindicate [Michigan’s] Constitution”).

112 Echeverria, supra note 83, at 38.

113 Id. 
There is a very small group of real estate people who are professional holdouts. ...

Finally there is the foolish holdout. Motivated by spite, by a need to defy anyone in a position of perceived power or authority, by a desire for publicity or notoriety, or by sheer cussedness, this sort of holdout is perhaps the most difficult to deal with because he cannot be reached with reason and will not respond to rational offers. ${ }^{114}$

According to this view, there is nothing praiseworthy or honorable about those who stand in the way of the Kelo majority's notion of progress or public good. One commentator recently described these individuals, like Ms. Kelo, as a "problem that afflicts infrastructure projects [and] also commonly afflicts redevelopment projects of the kind at issue in the Kelo case." 115 The same commentator suggested that these people stand in the way of revitalizing American cities and suburbs, proving the need for the use of eminent domain to "facilitate urban revitalization." 116

These views are problematic on numerous counts, but two stand out. First, they are anathema to a fundamental notion that one of the rights of property owners is the right to say no, to exclude-the right to holdout. ${ }^{117}$ Understanding the right to holdout as an extension of the right to exclude elevates it to a right that, as Justice Rehnquist once observed, is "universally held to be a fundamental element of the property right." 118 Certainly, property rights are not absolute, but neither are they as porous as these disparaging views of holdouts suggest. And neither are holdouts-property owners merely exercising fundamental rights-deserving of these disparaging views.

Second, this virtual disdain of holdouts in the face of urban economic development completely ignores the real and substantive challenges that legal and economic scholars have raised about the veracity of the holdout explanation as a justification for eminent domain. In their paper, Takings and Tax Revenue: Fiscal Impacts of Eminent Domain, economists Carrie Kerekes and Dean Stansel cite to work from as early as 1976 that raises real challenges to the validity of the holdout justification. ${ }^{119}$ They argue that eminent domain actually hampers economic development because of the economic inefficiencies eminent domain introduces, explaining "that takings for private economic development result in zero-sum games" and challenging the idea that eminent domain is "more efficient than the private

\footnotetext{
114 ANDREW AlPERn \& SEYMOUR DURST, Holdouts!: THE BuILdings THAT GOT IN THE WAy 1 (3d ed. 2011).

115 Echeverria, supra note 83, at 38.

116 Id. at 39.

117 Famously, in Kaiser Aetna v. United States, 444 U.S. 164, 176 (1979), the United States Supreme Court said that the right to exclude others was "one of the most essential sticks in the bundle of rights that are commonly characterized as property."

118 Id. at $179-80$.

119 Kerekes \& Stansel, supra note 91, at 9.
} 
sector at assembling land." ${ }^{120}$ Kerekes and Stansel use what they describe as a more precise model for testing the fiscal impacts of eminent domain and "fail to find evidence of a statistically significant relationship between eminent domain activity and the level of state and local government revenue." ${ }^{121}$ Despite these truths, states diverge on their treatment of eminent domain post-Kelo.

\section{B. The Eminent-Domain "Laboratories" and the Virtue of Michigan}

Many states remain strong supporters of eminent domain for economic development ${ }^{122}$ despite (1) evidence of the lack of a positive correlation between eminent domain and state and local revenue; ${ }^{123}$ (2) targeting of politically disadvantaged and disenfranchised groups for eminent domain; ${ }^{124}$ and (3) "the exacerbating effects of eminent domain for private development [on the poor.]" ${ }^{125}$ In these states, the majority and politically powerful appear unaware or unconcerned about the real costs and disproportionate effects on especially vulnerable populations caused by eminent domain for economic development. This impact has earned the name, the "reverse Robin Hood." ${ }^{226}$ While the heroic Robin Hood stole from the wealthy and gave to the poor, Kelo-esque exercises of eminent domain for economic development take from those who have the least and give to the Pfizers of the world. ${ }^{127}$

Not every state has been so charitable toward an expanded notion of public use and virtually unchecked powers in the realm of takings. ${ }^{128}$ Michigan is an example of a state that has pushed back against economic- development takings. ${ }^{129}$ While the Kelo case was working its way through the federal court system, the Michigan Supreme Court was reconsidering its 1981 decision in Poletown v. City of Detroit. ${ }^{130}$ Poletown was the state analogue of Kelo; it blessed economic-development takings and a broad interpretation of public use or purpose. And there are important analogies to be drawn between Poletown and Kelo-most notably, the intensely political

\footnotetext{
120 Id.

121 Id. at 17.

122 Echeverria, supra note 83, at 40; Kerekes \& Stansel, supra note 91, at 24, 57.

123 Kerekes \& Stansel, supra note 91, at 24, 57.

124 Kelo v. City of New London, 545 U.S. 469, 521-23 (2005) (Thomas, J., dissenting); Carpenter

\& Ross, supra note 1, at 2456.

125 Carpenter \& Ross, supra note 1, at 2456.

126 Id. at 2457; Kanner, supra note 60, at 206.

127 Carpenter \& Ross, supra note 1, at 2456; Kanner, supra note 60, at 206.

128 Somin, supra note 2, at 142 (discussing post-Kelo state reforms).

129 Brief of Amici Curiae NAACP et al. in Support of Petitioners, supra note 1, at 19.

130 Cty. of Wayne v. Hathcock, 684 N.W.2d 765, 787 (Mich. 2004) (overruling Poletown Neighborhood Council v. City of Detroit, 304 N.W.2d 455 (Mich. 1981) (per curiam)).
} 
nature of the decision to take in both cases and the failure of the promised economic returns that, for the majority in each case, justified the takings. ${ }^{131}$ The Poletown neighborhood was condemned under a plan by the Detroit Economic Development Corporation for transfer to General Motors ("GM"), a private corporation. ${ }^{132}$ The plan called for construction of an assembly plant in order to promote industry and commerce, add jobs, increase taxes, and improve the economic base of Detroit and of the state. ${ }^{133}$ In a landmark 5-2 decision, the Michigan Supreme Court ruled against the residents and rejected their argument that the exercise of eminent domain was unconstitutional because the primary beneficiary of the condemnation was a private entity, not the public. ${ }^{134}$ Dissenting from the Poletown majority, Justice Fitzgerald wrote:

Now that we have authorized local legislative bodies to decide that a different commercial or industrial use of property will produce greater public benefits than its present use, no homeowner's, merchant's or manufacturer's property, however productive or valuable to its owner, is immune from condemnation for the benefit of other private interests that will put it to a "higher" use. ${ }^{135}$

Justice O'Connor, in her Kelo dissent, remarked on the prescience of Justice Fitzgerald's warning in Poletown. ${ }^{136}$ Ultimately, just as in Kelo, the promised economic benefits that justified the Poletown majority's decision to permit the taking did not come to fruition. ${ }^{137}$

131 John J. Bukowczyk, The Decline and Fall of a Detroit Neighborhood: Poletown vs. G.M. and the City of Detroit, 41 WASH. \& LEE L. REv. 49, 60-64 (1984) (discussing the influence of state and federal legislation, G.M.'s promises of jobs and revenue, and the diverse and complicated motives of the political actors involved); Ilya Somin, Overcoming Poletown: County of Wayne v. Hathcock, Economic Development Takings, and the Future of Public Use, 2004 MicH. ST. L. REV. 1005, 1013 (noting that even at the peak of the 1990 's boom, the GM plant's workers numbered "less than $60 \%$ of the promised 6,150”).

132 Poletown, 304 N.W.2d at 457.

133 Id. For a history of the Poletown community, see Bukowczyk, supra note 131.

134 Poletown, 304 N.W.2d at 460.

135 Id. at 464 (Fitzgerald, J., dissenting).

136 Kelo v. City of New London, 545 U.S. 469, 504-05 (2005) (O’Connor, J., dissenting) (quoting id.).

137 The Castle Coalition has stated:

In the 1981 Poletown decision, a seminal case credited with providing the rationale for the widespread use of eminent domain for private profit, the Michigan Supreme Court allowed the City of Detroit to seize and bulldoze an entire neighborhood so General Motors could build an auto plant. In total, more than 4,200 people were displaced from their homes, and the government's wrecking ball claimed 140 businesses, 6 churches, several non-profits and one hospital. GM paid Detroit $\$ 8$ million for the property, while the City paid more than $\$ 200$ million to acquire and prepare the land for the automobile giant. A total of \$150 million in federal loans and grants, combined with more than \$30 million in state government funds, enabled the City to make the purchase.

Remarkably, in addition to destroying a historic, racially diverse community, the redevelopment project failed to meet its many promises and expectations. Detroit Mayor Coleman Young and General Motors promised that the redevelopment project would create more 
The Michigan Supreme Court overruled Poletown twenty-three years later in County of Wayne v. Hathcock. ${ }^{138}$ The Hathcock court called the Poletown decision a "radical and unabashed departure" from its eminent domain jurisprudence. ${ }^{139}$ It rejected the Poletown majority's extreme deference to the legislature's determination of what is a public purpose, ${ }^{140}$ even quoting Justice Ryan's Poletown dissent, in which he stated:

\footnotetext{
In point of fact, this Court has never employed the minimal standard of review in an eminent domain case which is adopted by the majority in this case. Notwithstanding explicit legislative findings, this Court has always made an independent determination of what constitutes a public use for which the power of eminent domain may be utilized. ${ }^{141}$
}

Article 10, section 2 of the 1963 Michigan Constitution authorized condemnation of private property for public use and upon payment of just compensation. ${ }^{142}$ According to the court, "public use" was the operative phrase, and it held that the public use requirement can be met when condemned property is transferred to a private entity when one of three tests is met. Citing to Justice Ryan's Poletown dissent, the Hathcock court articulated three independent tests that could justify exercise of eminent domain and transfer of private property to a private corporation in cases not involving instrumentalities of commerce: (1) the condemnation involves "extreme" public necessity; (2) "the private entity remains accountable to the public in its use" of the condemned property; and (3) selection of the condemned land "is itself based on public concern." "143

Why is it that, as was the case in Poletown and Kelo, "[i]t is common that the rosy projections made when redevelopment projects are commenced fall short of reality"? ${ }^{144}$ The answer is because those who promise redevelopment are often not held accountable. ${ }^{145}$ Importantly, the Hathcock court addressed the accountability problem in articulating these three tests.

than 6,000 jobs-but when all was said and done, the plant employed less than half that many. By 1988, the plant employed merely 2,500 people. In fact, it is estimated that the destruction of the entire Poletown neighborhood probably resulted in a net loss of jobs. The City's own estimates conclude that about one-third of the businesses displaced by the project closed immediately. This underscores even further just how much of a failure the project was.

Castle Coal., Inst. for Justice, Redevelopment Wrecks: 20 Failed Projects Involving EMINENT DOMAIN ABUSE 5-6 (2006) (footnotes omitted), http://castlecoalition.org/pdf/ publications/Redevelopment\%20Wrecks.pdf.

138684 N.W.2d 765, 787 (Mich. 2004).

139 Id. at 785.

140 Id. at 785-87 (quoting Poletown, 304 N.W.2d at 475 (Ryan, J., dissenting)).

141 Poletown, 304 N.W.2d at 475 (Ryan, J., dissenting).

142 Hathcock, 684 N.W.2d at 779 (quoting Mich. Const. art. X, § 2.)

143 Id. at 781-83 (citing Poletown, 304 N.W.2d at 478 (Ryan, J. dissenting)).

144 Kanner, supra note 60, at 225.

145 Somin, supra note 2, at 76-78. 


\section{If the Hathcock Tests Had Been Applied to Kelo}

If the United States Supreme Court had considered the Hathcock tests, the result in Kelo likely would have been different. First, the Hathcock court understood extreme public necessity ${ }^{146}$ to be limited to "those enterprises generating public benefits whose very existence depends on the use of land that can be assembled only by the coordination central government alone is capable of achieving." ${ }^{147}$ And the court listed "instrumentalities of commerce" like highways, canals, and railroads as exemplars of this type of necessity. ${ }^{148}$ Office and business parks are inherently different in their design from these types of instrumentalities of commerce and, therefore, according to the Hathcock court, do not require the same type of coordinated government effort to achieve them. ${ }^{149}$ Railways and highways need to be straight and connected, and centers of business enterprise do not demand the same connectedness and precision of location. ${ }^{150}$

Second, the lack of binding obligations in Kelo, ${ }^{151}$ Poletown, ${ }^{152}$ and Hathcock $^{153}$ meant that the new owners were not required to produce the

146 See Robert C. Bird \& Lynda J. Oswald, Necessity as a Check on State Eminent Domain Power, 12 U. PA. J. CONST. L. 99 (2010) (arguing for a revival of the necessity doctrine as a constraint on the exercise of eminent domain).

147 Hathcock, 684 N.W.2d at 781 (quoting Poletown, 304 N.W.2d at 478 (Ryan, J., dissenting)) (internal quotation marks omitted).

148 Id. (quoting Poletown, 304 N.W.2d at 478 (Ryan, J., dissenting)) (internal quotation marks omitted).

149 Id. at 783-84.

150 Id. at 781-83.

151 See supra notes 49-51 and accompanying text (discussing the failure of the Pfizer project to deliver the promised economic benefits).

152 Justice Ryan aptly raised the issue of accountability:

One of the reasons advanced by the defendants as justification of the taking in this case, and adopted by the majority, is the claim of alleviation of unemployment. Even assuming, arguendo, that employment per se is a "necessity of the extreme sort", there are no guarantees from General Motors about employment levels at the new assembly plant. General Motors has made representations about the number of employees who will work at the new plant, and I certainly do not doubt the good faith of those representations. But the fact of the matter is that once CIP is sold to General Motors, there will be no public control whatsoever over the management, or operation, or conduct of the plant to be built there. General Motors will be accountable not to the public, but to its stockholders. Who knows what the automotive industry will look like in 20 years, or even 10? For that matter, who knows what cars will look like then? For all that can be known now, in light of present trends, the plant could be fully automated in 10 years. Amid these uncertainties, however, one thing is certain. The level of employment at the new GM plant will be determined by private corporate managers primarily with reference, not to the rate of regional unemployment, but to profit.

By permitting the condemnation in this case, this Court has allowed the use of the public power of eminent domain without concomitant public accountability.

Poletown, 304 N.W.2d at 480 (Ryan, J., dissenting).

153 Hathcock, 684 N.W.2d at 784 ("The public benefit arising from the [project] is an epiphenomenon of the eventual property owners' collective attempts at profit maximization. No formal mechanisms exist to ensure that the businesses that would occupy what are now defendants' properties will continue to contribute to the health of the local economy."). 
promised benefits that were relied upon to justify the use of eminent domain. ${ }^{154}$ As Justice Ryan so appropriately observed in his Poletown dissent, public officials had no control over GM's market-based hiring decisions because "employment at the new GM plant [was] determined by private corporate managers primarily with reference, not to the rate of regional unemployment, but to profit.” ${ }^{155}$ Perhaps unsurprisingly then, absent any legally binding obligations in the Kelo and Poletown cases, the promised benefits ultimately fell short.

Third, in Kelo, there were no facts of independent public significance, unrelated to the private interests of Pfizer, that warranted the exercise of eminent domain. This was also the case in Poletown ${ }^{156}$ and Hathcock. ${ }^{157}$ In other words, the only public benefits cited to justify the Kelo condemnations were benefits that would arise after the private properties were condemned and transferred to Pfizer. There was nothing about the pure act of the condemnations themselves that created a public benefit. The condemned properties were not blighted or in disrepair and many were occupied residences - so no public safety or health needs were promoted by the takings due to such justifications as blight remediation. ${ }^{158}$ This fact distinguished the condemnations in Kelo from those in Berman v. Parker ${ }^{159}$ and Hawaii Housing Authority v. Midkiff ${ }^{160}$ that Justice Stevens cited as evidence of the Court's deference to state courts and state legislatures in determining when the use of the taking power is justified by public needs. ${ }^{161}$ Justice O'Connor, author of the majority opinion in Midkiff, pushed back on the Kelo majority's use of these two cases as guiding precedents. ${ }^{162}$ In her Kelo dissent, Justice O’Connor wrote:

Yet for all the emphasis on deference, Berman and Midkiff hewed to a bedrock principle without which our public use jurisprudence would collapse: “A purely private taking could not withstand the scrutiny of the public use requirement; it would serve no legitimate purpose of government and would thus be void.” ....

The Court's holdings in Berman and Midkiff were true to the principle underlying the Public Use Clause. In both those cases, the extraordinary, precondemnation use of the targeted property inflicted affirmative harm on society - in Berman through blight resulting from extreme poverty and in Midkiff through oligopoly resulting from extreme wealth. And in both cases, the relevant legislative body had found that eliminating the existing property use was

154 Somin, supra note 2, at 76.

155 Poletown, 304 N.W.2d at 480 (Ryan, J., dissenting).

156 Id. (stating that facts of private-not public-significance dictated the choice of the Central Industrial Park location).

157 Hathcock, 684 N.W.2d at 784 (stating that the only public benefits arise only after the condemnation and transfer into private hands and that there was nothing about the condemnation act itself that served a public good).

158 Kelo v. City of New London, 545 U.S. 469, 500-01 (2005) (O’Connor, J., dissenting).

159348 U.S. 26 (1954).

160467 U.S. 229 (1984).

161 Kelo, 545 U.S. at 483.

162 Id. at 499-501 (O’Connor, J., dissenting). 
necessary to remedy the harm. Thus a public purpose was realized when the harmful use was eliminated. Because each taking directly achieved a public benefit, it did not matter that the property was turned over to private use. Here, in contrast, New London does not claim that Susette Kelo's . . . well-maintained home[] [is] the source of any social harm. ${ }^{163}$

As Justice Stevens suggested, might the answer to the Kelo problem lie with the states that have the ability to enact more restrictions on the exercise of the power to take if they do not like the United States Supreme Court's expanding use of the Public Use Clause in favor of economic development? ${ }^{164}$ Certainly, post-Kelo, many states responded with reforms designed to limit or forbid condemnations for economic development. ${ }^{165}$ But how effective might these post-Kelo restrictive state statutes be when the exercise of eminent domain for economic development is analyzed under federal law? The answer is: not very. For example, in Whittaker $v$. County of Lawrence, ${ }^{166}$ the federal district court declined to apply a restrictive definition of "blight" from a Pennsylvania statute in a Fifth Amendment challenge to the use of eminent domain to support a high-tech business park development. ${ }^{167}$ In refusing to apply the state statutory restrictions on the use of eminent domain, the court stated that, "[a]s far as the United States Constitution is concerned, a 'public use' in Connecticut is a 'public use' in Pennsylvania. The Plaintiffs attempt to convert state statutory standards into federal constitutional requirements, '[b]ut constitutional law does not work that way.", 168

\section{CONCLUSION}

As Justice Scalia once said, some issues "come before the Court clad, so to speak, in sheep's clothing: the potential of the asserted principle to effect important change in the equilibrium of power is not immediately evident, and must be discerned by a careful and perceptive analysis. But this wolf comes as a wolf." 169 And the same is true of Kelo-the wolf comes as a wolf, and it comes as a wolf to prey on the most vulnerable and least politically powerful groups. Destabilization, disenfranchisement of vulnerable groups, illusive and incidental benefits-these are the concerns of the Kelo dissenters, particularly Justice Thomas. The Hathcock tests address some of these concerns in the state constitutional context while also

163 Id. at 500 (citations omitted) (quoting Midkiff, 467 U.S. at 245).

164 Id. at 489 (majority opinion).

165 Echeverria, supra note 83, at 41.

166674 F. Supp. 2d 668 (W.D. Pa. 2009), aff'd, 437 F. App’x 105 (3d Cir. 2011).

167 Id. at 688-89.

168 Id. at 689-90 (footnote omitted) (quoting Cruzan v. Dir., Mo. Dep’t of Health, 497 U.S. 261, 286 (1990)).

169 Morrison v. Olson, 487 U.S. 654, 699 (1988) (Scalia, J., dissenting). 
hewing more closely to the original meaning of the Public Use Clause as eloquently expressed by Justice Thomas. In the absence of such limitations and as the frequency and magnitude of these joint ventures increase, so too does the distance between the original understanding of the Public Use Clause and the legitimate exercise of the eminent domain power when the state participates in economic development. ${ }^{170}$

170 See Brown, supra note 1, at 149-64. 